\title{
INTERAKSI FAKTOR POLIMORPHISME GEN ENDHOTELIAL NITRIC OXIDE SINTASE (eNOS) DENGAN FAKTOR - FAKTOR RESIKO TERHADAP PREGNANT INDUCED HYPERTENSION (PIH)
}

\author{
Mochammad Erwin Rachman \\ Fakultas Kedokteran Universitas Muslim Indonesia \\ Email : erwin.rachman@yahoo.co.id
}

\begin{abstract}
The aim of the study was to discover the effect of interaction polymorphism endhotelial nitric oxide synthase (eNOS) polymorphism gene with mother's age, parity, and body mass index (BMI) on the incidence of Pregnant Induced Hypertension (PIH) using a nested case control study. The number of subjects was 29 pregnant mothers whose pregnancy was $\geq 20$ weeks. The examination of endotelial nitric oxide synthase (eNOS) polymorphism gene was done by polymerase chain reaction (PCR) modified by Rigat. The result of the study indicate that the nitric oxide synthase (eNOS) polymorphism gene of genotype GG the risk more than the genotype non GG. Genotype GG 1,8 means that the risk for hypertension is high, and the age less than 20 years and over 35 years has 3,78 times risk for $\mathrm{PIH}$, while at the multípara, the risk is 2,16 times compared to the primípara. So that at the high BMI , the risk is 1,67 times compared to the normal $B M I$. Interaction of the genotype $G G$ and ages $<20$ years and $>35$ years have risk for PIH will have a greater risk for PIH than another of the interaction genotype non GG, parity, and BMI. Interaction between gene factor with environment will enlarge risk suffer PIH.
\end{abstract}

Keyword : Pregnant induced hypertension, mother's age, parity, BMI, eNOS gen polymorphism.

\section{PENDAHULUAN}

Salah satu dari tiga penyebab utama kematian ibu dan perinatal di Indonesia adalah hipertensi karena kehamilan (Pregnancy Induced Hypertension / PIH) yang sampai saat ini merupakan masalah dalam obstetri, bentuk manifestasinya berupa gestational hypertensi (hipertensi yang timbul pada kehamilan > 20 minggu), preeklampsia (hipertensi gestasi dengan proteinuri), eklampsia ( jika gejala preeklampsia berlanjut dan timbul kejang dan atau koma). (I.K. Suwiyoga, dkk 2004).

Sampai saat ini beberapa penelitian yang dilakukan untuk mencari faktor penyebab kelainan ini, masih menghasilkan beberapa hasil yang saling bertentangan dan ditemukan bahwa kelainan ini didasari oleh banyak faktor.(Joey P. Granger et 
al. 2001) . Angka mortalitas dan morbiditas maternal yang disebabkan oleh hipertensi karena kehamilan terjadi pada $5-10 \%$ kehamilan. Angka kejadian preeklampsia di Indonesia masih cukup tinggi sekitar 4,7 - 7,0 \%, dengan angka kematian berkisar antara 30 - $40 \%$ untuk preeklampsia berat dan $60-80 \%$ untuk eklampsia. (Aashit Ks,Hypertension 2007) . Angka kejadian eklampsia sekitar 28\% pada wanita tanpa sebelumnya didiagnosis sebagai preeklampsia. Tingginya angka morbiditas dan mortalitas ibu hamil disebabkan sulitnya mendiagnosis secara dini kelainankelainan ini serta penanganan yang terlambat dilakukan, terutama pada daerah perifer dengan jarak rumah dan fasilitas kesehatan yang jauh. Dengan demikian, upaya penanggulangan penyakit ini dan komplikasinya menjadi hal yang sangat penting dan perlu mendapat perhatian lebih untuk menurunkan angka kematian ibu dan anak khususnya dan upaya peningkatan sumber daya manusia Indonesia umumnya.

Hipertensi karena kehamilan (PIH) menyebabkan terjadinya gangguan sirkulasi uteroplasental pada ibu, mengakibatkan berkurangnya perfusi plasenta, dan mengganggu pertumbuhan janin berakibat terjadi Kecil Masa Kehamilan (KMK). Angka kejadian KMK di beberapa rumah sakit di kota Makassar cukup tinggi yaitu sekitar 20 $\%$ dari kelahiran bayi.

Adapun faktor-faktor resiko untuk terjadinya $\mathrm{PIH}$, meliputi : Nullipara, usia ibu hamil diatas 40 tahun, adanya riwayat keluarga yang mederita $\mathrm{PIH}$, menderita hipertensi kronik, menderita gagal ginjal kronik, Diabetes melitus (DM), kehamilan kembar, ras atau suku bangsa, dan adanya polimorphisme gen Angiatensin. (americanpregnancy . 2002). Sedangkan menurut (The Cleveland Clinic (c) 1995-2008). Faktor -faktor resiko untuk menderita $\mathrm{PIH}$ sebagai berikut : usia ibu kurang dari 20 tahun dan lebih 35 tahun, mempunyai riwayat keluarga yang menderita $\mathrm{PIH}$, mempunyai riwayat hipertensi kronik, ibu hamil yang memiliki berat badan criteria underweight dan overweight, menderita DM sebelum hamil, memiliki gangguan system imunitas seperti arthritis rheumatoid atau lupus, memiliki gangguan fungsi ginjal, memiliki riwayat minum minuman beralkohol dan perokok, serta mengandung anak kembar atau lebih. 
\begin{tabular}{lrr}
\multicolumn{1}{c}{ Etiologi Hipertensi } & karena \\
kehamilan (Pregnancy Induced & Iiketahui \\
Hypertension=PIH) belum d
\end{tabular} secara pasti dan bersifat multifaktorial, tetapi secara luas telah diterima bahwa disfungsi endotel mempunyai peran penting terhadap terjadinya $\mathrm{PIH}$ dan PE. Disfungsi endotel disebabkan oleh karena adanya defek pada invasi trofoblas plasenta selama implantasi menyebabkan tidak sempurnanya remodelling arteri spiralis., Perfusi plasenta menurun dan menyebabkan iskemia plasenta. Iskemia plasenta akan meningkatkan stress oksidatif yang selanjutnya merangsang pembentukan dan pelepasan placental faktor seperti TNF- $\alpha$ yang menyebabkan aktivasi dan disfungsi endotel. Disfungsi endotel akan menyebabkan peningkatan sintesis ET-1 dan TXA2, aktifasi sistem reninangiotensin dan peningkatan sensitifitas terhadap Angiotensin-II serta penurunan sintensis NO dan PGE2. Peningkatan aktivitas Angiotensin- II dipicu oleh ACE yang akan memicu sintesis ET-1 sebagai kompensasi terhadap peningkatan tekanan darah. Pada awalnya kenaikan ET-1 akan memicu produkasi NO untuk mengimbangi kenaikan ET1. Bila tekanan darah terus meningkat akan terjadinya gangguan fungsi endotel, dimana Ang II dan ET-1 meningkat tetapi NO menurun. Hal ini mungkin disebabkan oleh adanya pengaruh polimorphisme endothelial nitric oxide synthase (eNOS) gen yang mestinya berespon memproduksi nitric oxide dalam jumlah cukup tetapi malah menurunkan produksi nitric oxide, sehingga pembuluh darah akan bervasokontriksi. Dengan demikian, adanya faktor-faktor tersebut yang terjadi pada ibu hamil inilah yang mendasari terjadinya PIH dan PE .

Adanya temuan yang mengindikasikan bahwa polymorfisme endothelial nitric oxide Glu298Asp synthase (eNOS) gen itu berhubungan dengan perbedaan didalam pelebaran endothelium pada kehamilan 12 minggu dan merupakan implikasi faktor genetik pertama didalam adaptasi normal vaskuler terhadap kehamilan. Mereka juga memberikan suatu mekanisme potensial yang menghubungkan polymorfisme endothelial nitric oxide Glu298Asp synthase (eNOS) gen dengan perkembangan dari kelainan cardiovaskuler dan telah mempunyai implikasi terhadap pengertian basis genetik dari preeclampsia. (Hypertension, 2001;38:1289-1293).

Berdasarkan data-data tersebut kami akan melakukan penelitian 
interaksi polimorphisme endothelial nitric oxide synthase (eNOS) gen dengan faktor paritas, primipara dan Index Massa Tubuh terhadap kejadian hipertensi karena kehamilan (PIH).

\section{METODE PENELITIAN}

Rancangan penelitian adalah Nested kohort control study. Subyek penelitian adalah ibu hamil yang melakukan pemeriksaan antenatal care di RSB Fatimah, RSB Restu, dan Pusat Kegiatan Penelitian Kampus UNHAS dengan usia kehamilan $\geq 20$ minggu (trimester II) yang memenuhi kriteria inklusi yaitu mempunyai riwayat $\mathrm{PIH}$ dan hipertensi dalam keluarga, serta bersedia mengikuti prosedur penelitian dengan menandatangani informed consent. Adapun sampel yang tidak diikutsrtakan dalam penelitian, yaitu terjadi perdarahan antepartum, terminasi kehamilan, dan abortus.

Variabel-varibel penelitian kami yaitu ; umur, paritas, dan Index Massa Tubuh (IMT) ibu hamil, serta polimorphisme eNOS gen Glu298Asp . Cara yang dipakai untuk mengetahui umur dan paritas sampel melalui tehnik anamnesis. Sedangkan Alat yang digunakan untuk mengukur IMT dengan alat pengukur tinggi dan berat badan . Tekhnik pemeriksaan polimorphisme eNOS gen Glu298Asp melalui metode Polymerase Chain Reaction (PCR). Data hasil penelitian diolah menggunakan SPSS Windows versi 12,0 melalui metode análisis crosstab-chisquare.

Prosedur penelitian kami adalah sebagai berikut : Ibu hamil dengan usia kehamilan $\geq 20$ minggu yang melakukan pemeriksaan antenatal care di Rumah Sakit Ibu dan Anak Siti fatimah Makassar dan RSB Restu, akan diberi penjelasan dan diminta untuk terlibat dalam penelitian ini setelah menandatangani informed consent tentang prosedur pelaksanaan pengambilan sampel. Sampel dianamnesis untuk mengetahui umur dan paritasnya, sedangkan untuk mendapatkan IMT dilakukan dengan mengukur tinggi dan berat badan sampel dengan rumus singkatnya adalah :

$$
\text { IMT }\left(\mathrm{Kg} / \mathrm{m}^{2}\right)=\text { Berat Badan }(\mathrm{Kg}) / \text { Tinggi Badan }\left(\mathrm{m}^{2}\right)
$$

Kriteria disesuaikan dengan hasil yang terdapat pada table dibawah 
Tabel Klasifikasi kegemukan untuk orang Asia

\begin{tabular}{lc}
\multicolumn{1}{c}{ Klasifikasi } & IMT (kg/m2) \\
\hline Berat badan kurang & $<18,5$ \\
\hline Normal & $18,5-22,9$ \\
\hline Overweight (berat badan lebih) & $\geq 23,0$ \\
\hline - $\quad$ Beresiko & $23,0-24,9$ \\
\hline - Obesitas Tingkat I & $25,0-29,9$ \\
\hline - Obesitas Tingkat II & $\geq 30,0$ \\
\hline
\end{tabular}

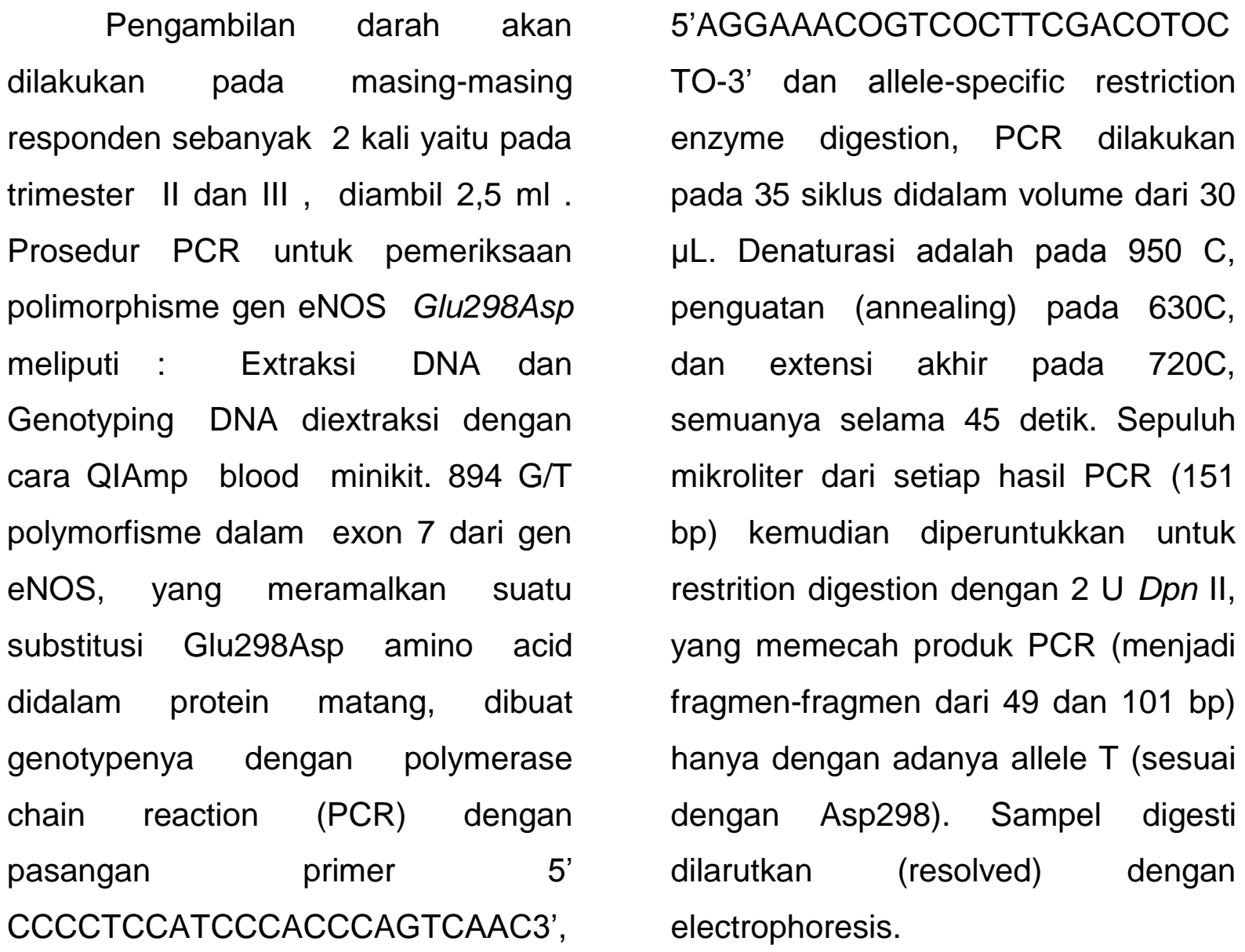




\section{Hasil RFLP}

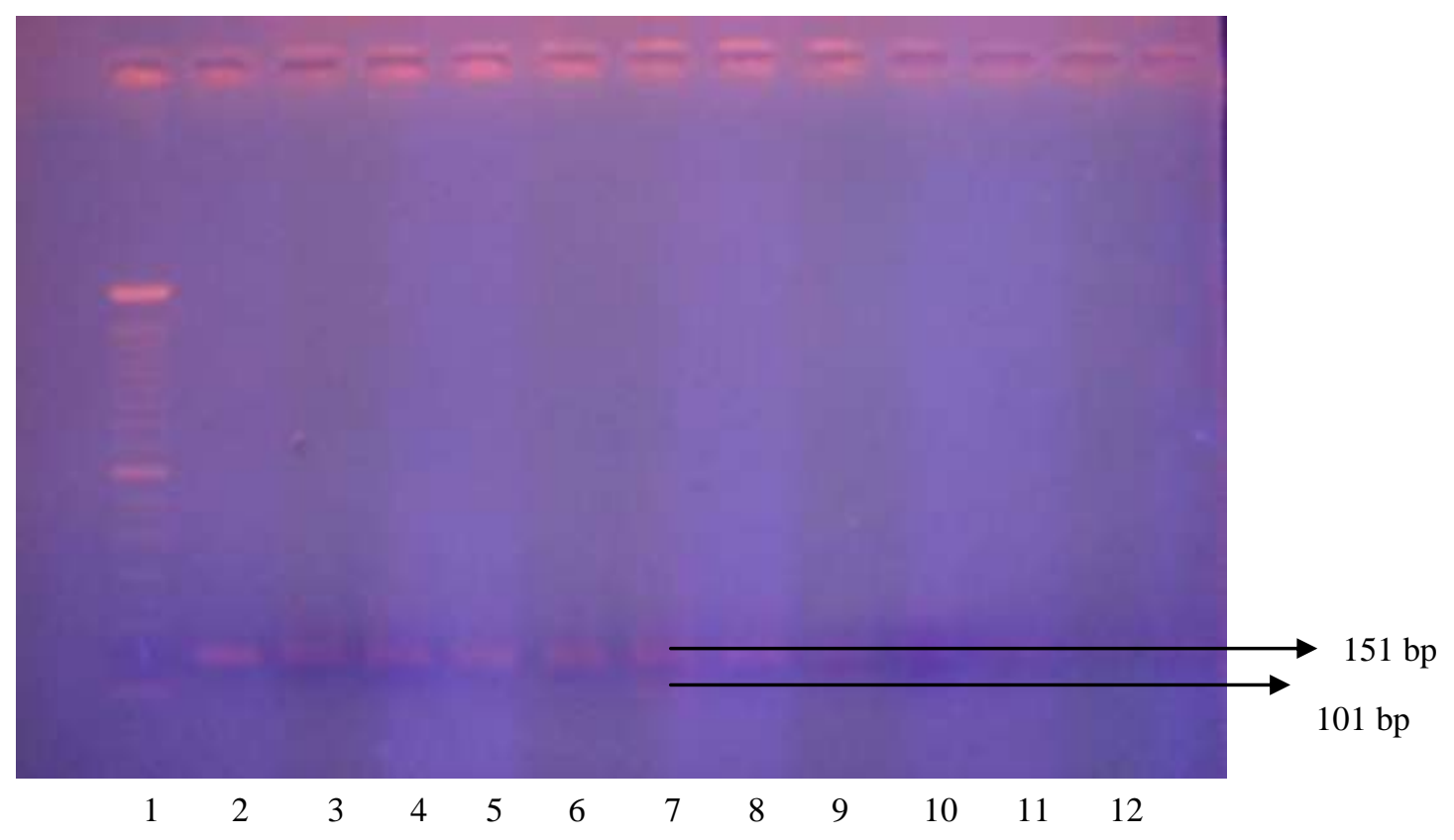

GG = Marker $151 \mathrm{bp}$

GT = Marker $151 \mathrm{bp}, 101 \mathrm{bp}$,

TT = Marker $101 \mathrm{bp}, 49 \mathrm{bp}$

\section{Keterangan :}

Line $1=$ Marker $101 \mathrm{bp}$

Line $3=$ Sampel $1=\mathrm{GG}$

Line $5=$ Sampel $3=$ GG

Line $7=$ Sampel $5=G T$

Line $9=$ Sampel $26=\mathrm{GT}$

Line $11=$ sampel $28=G G$

$\begin{array}{lll}\text { Line 2 } & =\text { uncut 151 bp } & \\ \text { Line 4 } & =\text { sampel 2 } & =\mathrm{GG} \\ \text { Line 6 } & =\text { sampel 4 } & =\mathrm{GG} \\ \text { Line } 8 & =\text { sampel 25 } & =\mathrm{GG} \\ \text { Line 10 } & \text { sampel 27 } & =\mathrm{GG} \\ \text { Line 12 } 12 & \text { sampel 29 } & =\mathrm{GG}\end{array}$

\section{HASIL PENELITIAN}

Data penelitian kami terkumpul sampel ibu hamil, terdiri dari 29 sampel, dengan 11 sampel PIH dan 18 sampel Non PIH sebagai kontrol. Adapun variabel penelitian yang kami amati merupakan faktor-faktor resiko untuk menderita $\mathrm{PIH}$, yaitu umur, paritas, index massa tubuh ibu hamil, dan polimorphisme eNOS gen pada ibu hamil, secara umum variabelvariabel penelitian kami dapat dilihat pada tabel 1. 
Tabel 1. Distribusi frekuensi variabel penelitian

\begin{tabular}{ccc}
\hline \multicolumn{1}{c}{ Variable } & $\mathbf{n}$ & $\%$ \\
\hline Umur (tahun) & 3 & \\
$-\quad$ Resiko & 26 & 10,3 \\
$-\quad$ Non Resiko & 10 & 89,7 \\
\hline Paritas & 19 & 34,4 \\
$-\quad$ Multipara & 10 & 65,6 \\
$-\quad$ Primipara & 14 & \\
\hline IMT & & 41,6 \\
$-\quad$ Tinggi & 24 & 58,4 \\
$-\quad$ Normal & 4 & 85,7 \\
\hline Gen eNOS & Genotype GG & 14,3 \\
\hline
\end{tabular}

$\mathrm{n}=$ jumlah sampel,$\%=$ persentase, $\mathrm{IMT}=$ Index Massa Tubuh.

Perbandingan antara variabelvariabel pada data kami, setelah diolah dengan menggunakan SPSS Versi 12,0 , didapatkan hasil bahwa tingkat signifikansi data kami semuanya kurang bermakna dengan tingkat signifikansi $p>0,05$. Meskipun demikian, kami mencoba melihat berdasarkan odd ratio dari masingmasing variable. Secara persentase tampak faktor umur dengan kelompok Resiko lebih banyak menderita $\mathrm{PIH}$ sebesar 66,7\% dibandingkan kelompok umur Nonresiko yang menderita PIH sebesar 34,6\% . Faktor paritas ibu hamil, tampak kelompok multipara lebih banyak menderita $\mathrm{PIH}$ sebesar $50 \%$ dibandingkan primipara hanya 31\%. Pada faktor IMT, terlihat kelompok IMT tinggi lebih banyak menderita $\mathrm{PIH}$ sebesar $40 \%$ dibandingkan kelompok IMT normal sebesar $28,6 \%$. Serta pada pengaruh polimorphisme eNOS gen, tampak terlihat genotype GG sebesar 37,5\% lebih besar dibandingkan kelompok genotype non GG hanya 25\%, hal ini tampak pada tabel 2.

Tabel 2. Perbandingan variabel peneltian pada PIH dan kontrol

\begin{tabular}{cccc}
\hline Varibel & $\begin{array}{c}\text { PIH } \\
\mathbf{n}(\%)\end{array}$ & $\begin{array}{c}\text { Kontrol } \\
\mathbf{n}(\%)\end{array}$ & $\mathbf{p}(<0,05)$ \\
\hline Umur (tahun) & & & \\
$-\quad$ Resiko & $2(66,7 \%)$ & $1(33,3 \%)$ & 0,27 \\
$-\quad 20<\mathrm{x}<35$ & $9(34,6 \%)$ & $17(65,4 \%)$ & \\
\hline Paritas & & & \\
$-\quad$ Multipara & $5(50 \%)$ & $5(50 \%)$ & 0,33 \\
$-\quad$ Primipara & $6(31,6 \%)$ & $13(68,4 \%)$ & 0,55 \\
\hline IMT & & & \\
$-\quad$ Tinggi & $4(40 \%)$ & $6(60 \%)$ & \\
$-\quad$ Normal & $4(28,6 \%)$ & $10(71,4 \%)$ & \\
& & & \\
\hline
\end{tabular}




\begin{tabular}{|c|c|c|c|}
\hline \multicolumn{4}{|l|}{ Gen eNOS } \\
\hline $\begin{array}{ll}\text { - } & \text { Genotype GG } \\
\text { - } & \text { Genotype non-GG }\end{array}$ & $\begin{array}{c}9(37,5 \%) \\
1(25 \%)\end{array}$ & $\begin{array}{c}15(62,5 \%) \\
3(75 \%)\end{array}$ & 0,62 \\
\hline
\end{tabular}

$\mathrm{n}=$ jumlah sampel,$\%=$ peresentase, $\mathrm{IMT}=$ Index Massa Tubuh, $\mathrm{PIH}=$ pregnant induced hypertension, kontrol $=$ tidak menderita $\mathrm{PIH}, \mathrm{p}=$ probabilitas

Hubungan faktor polimorphisme eNOS gen ibu hamil untuk menderita $\mathrm{PIH}$, secara persentase dan Odd Ratio (OR), tampak kelompok genotype GG lebih besar (37,5\%) dan lebih banyak beresiko menderita PIH (OR) 1,8 kali lebih besar dibandingkan dengan kelompok genotype non GG, yang tampak pada tabel 3 .

Tabel 3. Hubungan polimorphisme eNOS gen dengan PIH dan Kontrol

\begin{tabular}{ccccc}
\hline Varibel & PIH & $\begin{array}{c}\text { Kontrol } \\
\mathbf{n}(\%)\end{array}$ & $\begin{array}{c}\text { Total } \\
\mathbf{n}(\%)\end{array}$ & OR \\
\hline Genotype & & & & \\
$-\quad$ GG & $9(37,5 \%)$ & $15(62,5 \%)$ & $24(100 \%)$ & $1,8(0,16-20,02)$ \\
$-\quad$ Non-GG & $1(25 \%)$ & $3(75 \%)$ & $4(100 \%)$ & \\
\hline
\end{tabular}

$\mathrm{n}=$ jumlah sampel,$\%=$ peresentase, $\mathrm{PIH}=$ pregnant induced hypertension, kontrol $=$ tidak menderita $\mathrm{PIH}, \mathrm{OR}=$ Odd Ratio .

Pada tabel 4. Mengenai hubungan faktor umur ibu hamil untuk menderita $\mathrm{PIH}$, secara persentase dan Odd Ratio (OR), tampak kelompok umur Resiko lebih besar $(66,7 \%)$ dan lebih banyak beresiko menderita PIH (OR) 3,78 kali lebih besar dibandingkan dengan kelompok umur Non-resiko.

Tabel 4. Hubungan faktor umur dengan PIH dan Kontrol

\begin{tabular}{|c|c|c|c|c|}
\hline Varibel & $\begin{array}{c}\text { PIH } \\
\text { n (\%) }\end{array}$ & $\begin{array}{c}\text { Kontrol } \\
\text { n (\%) }\end{array}$ & $\begin{array}{l}\text { Total } \\
\text { n (\%) }\end{array}$ & OR \\
\hline \multicolumn{5}{|l|}{ Umur (tahun) } \\
\hline - Resiko & $2(66,7 \%)$ & $1(33,3 \%)$ & $3(100 \%)$ & $3,78(0,3-47,5)$ \\
\hline Non-resiko & $9(34,6 \%)$ & $17(65,4 \%)$ & $26(100 \%)$ & \\
\hline
\end{tabular}

$\mathrm{n}=$ jumlah sampel,$\%=$ peresentase, $\mathrm{IMT}=$ Index Massa Tubuh, $\mathrm{PIH}=$ pregnant induced hypertension, kontrol = tidak menderita $\mathrm{PIH}, \mathrm{OR}=$ Odd Ratio .

Hubungan faktor paritas ibu hamil untuk menderita $\mathrm{PIH}$, secara persentase dan Odd Ratio (OR), tampak kelompok multipara lebih besar (50\%) dan lebih banyak beresiko menderita PIH (OR) 2,16 kali lebih besar dibandingkan dengan kelompok primipara, yang tampak pada tabel 5 . 
Tabel 5. Hubungan faktor paritas dengan PIH dan Kontrol

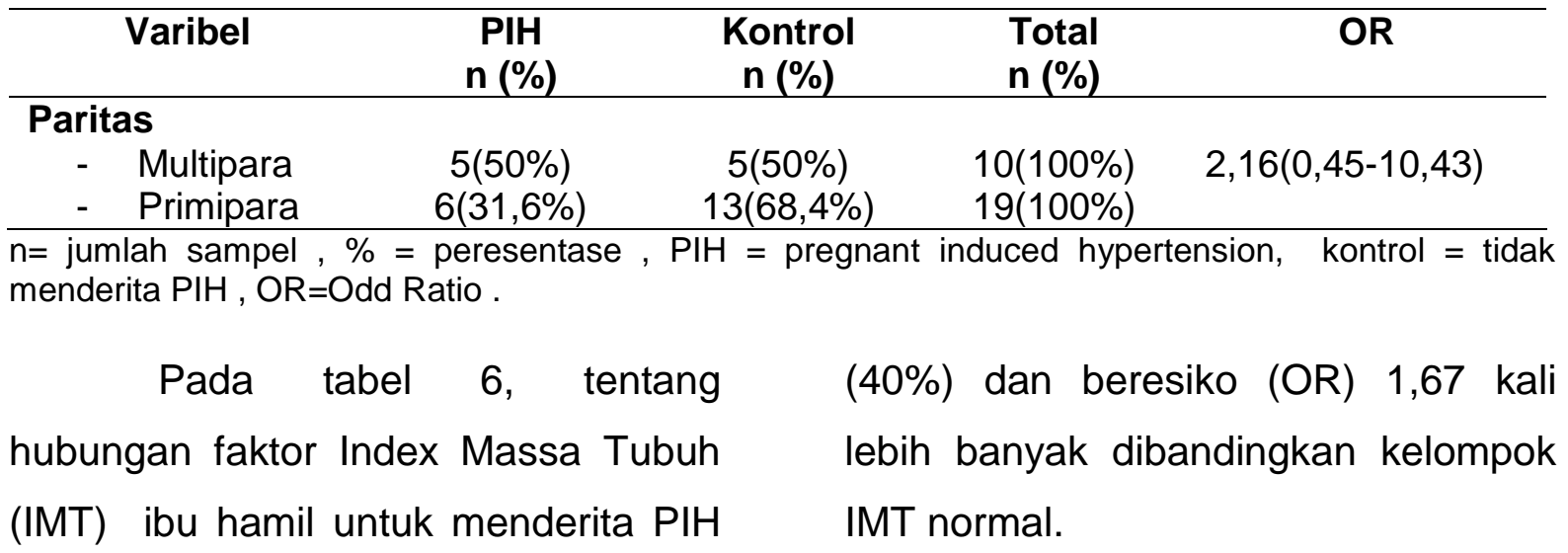
pada kelompok IMT tinggi lebih besar

Tabel 6. Hubungan faktor IMT dengan PIH dan Kontrol

\begin{tabular}{|c|c|c|c|c|c|}
\hline & Varibel & $\begin{array}{c}\text { PIH } \\
\text { n (\%) }\end{array}$ & $\begin{array}{c}\text { Kontrol } \\
\text { n (\%) }\end{array}$ & $\begin{array}{l}\text { Total } \\
\text { n (\%) }\end{array}$ & OR \\
\hline $\begin{array}{r}\text { IMT } \\
-\end{array}$ & $\begin{array}{l}\text { Tinggi } \\
\text { Normal }\end{array}$ & $\begin{array}{c}4(40 \%) \\
4(28.6 \%)\end{array}$ & $\begin{array}{c}6(60 \%) \\
10(71.4 \%)\end{array}$ & $\begin{array}{l}10(100 \%) \\
14(100 \%)\end{array}$ & $1,67(0,30-9,27)$ \\
\hline
\end{tabular}

$\mathrm{n}=$ jumlah sampel,$\%=$ peresentase, $\mathrm{IMT}=$ Index Massa Tubuh, $\mathrm{PIH}=$ pregnant induced hypertension, kontrol = tidak menderita PIH , OR=Odd Ratio .

Interaksi antara faktor dengan kelompok umur Non-resiko polimorphisme eNOS gen dengan sebesar $68 \%$ lebih besar dari umur ibu hamil untuk memperbesar kelompok umur Resiko. Sedangkan resiko untuk menderita $\mathrm{PIH}$, tampak interaksi antara polimorphisme eNOS interaksi pada kelompok interaksi gen genotype GG dan umur Resiko antara polimorphisme eNOS gen peningkatan resiko menjadi lebih genotype GG dan umur Resiko besar (OR) 4,25 kali dibandingkan sebesar $66,7 \%$ lebih besar dari pada kelompok genotype non GG , kelompok umur Non-resiko $(33,3 \%), \quad$ yang tampak pada tabel 7. dan interaksi antara genotype non GG

Tabel 7. Interaksi polimorphisme eNOS gen dengan umur pada PIH

\begin{tabular}{|c|c|c|c|}
\hline \multirow[t]{2}{*}{ Varibel } & \multicolumn{2}{|c|}{ Umur } & \multirow[t]{2}{*}{ OR } \\
\hline & Resiko & Non-resiko & \\
\hline $\begin{array}{cc}\text { Genotype } \\
-\quad \text { GG } \\
-\quad \text { Non-GG }\end{array}$ & $\begin{array}{c}2(66,7 \%) \\
8(32 \%)\end{array}$ & $\begin{array}{c}1(33,3 \%) \\
17(68 \%)\end{array}$ & $4,25(0,33-54,06)$ \\
\hline
\end{tabular}

$\mathrm{n}=$ jumlah sampel,$\%=$ peresentase, $\mathrm{PIH}=$ pregnant induced hypertension, kontrol $=$ tidak menderita $\mathrm{PIH}, \mathrm{OR}=$ Odd Ratio . 
Pada tabel 8. Interaksi antara faktor polimorphisme eNOS gen dengan faktor paritas ibu hamil untuk memperbesar resiko untuk menderita $\mathrm{PIH}$, tampak interaksi pada antara kelompok polimorphisme eNOS gen genotype GG dan primipara lebih besar $(62,5 \%)$ dibandingkan dengan interaksi genotype GG dengan multipara $(37,5 \%)$, serta interaksi pada antara kelompok polimorphisme eNOS gen genotype non GG dan primipara lebih besar (66,7\%) dibandingkan dengan interaksi genotype non GG dengan multipara (33,3\%). Adapun resiko untuk menderita $\mathrm{PIH}$ pada interaksi antara genotype GG dan primipara sebesar (OR) 1,2 kali dibandingkan genotype non GG.

Tabel 8. Interaksi polimorphisme eNOS gen dengan paritas pada $\mathrm{PIH}$

\begin{tabular}{|c|c|c|c|}
\hline \multirow[t]{2}{*}{ Varibel } & \multicolumn{2}{|c|}{ Umur } & \multirow{2}{*}{ OR } \\
\hline & Multipara & Primipara & \\
\hline \multicolumn{4}{|l|}{ Genotype } \\
\hline - GG & $6(37,5 \%)$ & $10(62,5 \%)$ & $1,20(0,25-5,76)$ \\
\hline - Non-GG & $4(33,3 \%)$ & $8(66,7 \%)$ & \\
\hline
\end{tabular}

Interaksi antara polimorphisme eNOS gen genotype non GG dengan kelompok ibu hamil IMT normal paling besar persentasenya yang menderita $\mathrm{PIH}(71,4 \%)$. Sedangkan resiko untuk menderita $\mathrm{PIH}$ pada interaksi antara genotype GG dengan IMT ibu hamil sebesar (OR) 1,25 kali dibandingkan genotype non GG, yang tampak pada tabel 9.

Tabel 9. Interaksi polimorphisme eNOS gen dengan IMT pada PIH

\begin{tabular}{|c|c|c|c|}
\hline \multirow{2}{*}{ Varibel } & \multicolumn{2}{|c|}{ IMT } & \multirow{2}{*}{ OR } \\
\hline & Tinggi & Normal & \\
\hline \multicolumn{4}{|l|}{ Genotype } \\
\hline - GG & $3(33,3 \%)$ & $6(66,7 \%)$ & $1,25(0,20-7,61)$ \\
\hline - Non-GG & $4(28,6 \%)$ & $10(71,4 \%)$ & \\
\hline
\end{tabular}

Pada tabel 10 dan tabel 11. Tampak tidak adanya sinergisme faktor-faktor resiko ibu hamil untuk memperbesar resiko menderita $\mathrm{PIH}$, dengan nilai Odd Ratio yang lebih kecil dibandingkan jika faktor-faktor tersebut berdiri sendiri atau saling berinteraksi.z 
Tabel 10. Sinergisme polimorphisme eNOS gen dengan paritas, umur pada PIH.

\begin{tabular}{|c|c|c|c|}
\hline Varibel & PIH & Kontrol & OR \\
\hline \multicolumn{4}{|l|}{ Genotype } \\
\hline - GG & $1(50 \%)$ & $1(50 \%)$ & $3,66(1,85-7,25)$ \\
\hline - $\quad$ Non-GG & $9(34,6 \%)$ & $17(65,4 \%)$ & \\
\hline
\end{tabular}

Tabel 11. Sinergisme polimorphisme eNOS gen dengan paritas, umur, dan IMT pada PIH.

\begin{tabular}{cccc}
\hline Varibel & PIH & Kontrol & OR \\
\hline Genotype & & & \\
$-\quad$ GG & $2(28,, 6 \%)$ & $5(71,4 \%)$ & $1,88(0,10-33,89)$ \\
$-\quad$ Non-GG & $5(31,3 \%)$ & $11(68,8 \%)$ & \\
\hline $\mathrm{n}=$ jumlah sampel , \% = peresentase, PIH = pregnant induced hypertension, kontrol = tidak \\
menderita PIH , OR=Odd Ratio
\end{tabular}

\section{PEMBAHASAN}

Penyebab kejadian PIH secara pasti masih kontroversial, dimana penyebab PIH dan preeklampsia yang diketahui diduga dipengaruhi oleh banyak faktor (multifaktorial) meliputi beberapa pola patomekanisme. Mekanisme yang penting terlibat seperti disfungsi endotel, autoimmunity, hiperaktifitas simpatis dan faktor genetik. (Menurut Dinesh M Shah (2005). Sedangkan faktor faktor resiko untuk menderita $\mathrm{PIH}$ sebagai berikut : usia ibu kurang dari 20 tahun dan lebih 35 tahun, mempunyai riwayat keluarga yang menderita $\mathrm{PIH}$, mempunyai riwayat hipertensi kronik, ibu hamil yang memiliki berat badan criteria underweight dan overweight, menderita DM sebelum hamil, memiliki gangguan system imunitas seperti arthritis rheumatoid atau lupus, memiliki gangguan fungsi ginjal, memiliki riwayat minum minuman beralkohol dan perokok, serta mengandung anak kembar atau lebih.(The Cleveland Clinic (C) 19952008).

Faktor umur yang lebih cenderung beresiko lebih besar untuk menderita PIH berdasarkan data-data kami setelah kami olah, baik melalui test crosstab-chisquare, maka secara persentase ternyata lebih banyak dari kelompok umur subyek kurang dari 20 dan lebih dari 35 tahun yang menderita PIH dibandingkan pada kelompok subyek yang berumur antara 20 tahun sampai 35 tahun, sertai juga jika kami melihat dari Odd Ratio (OR) untuk umur ibu hamil yaitu pada umur kurang dari 20 dan lebih dari 35 tahun sebesar $\mathbf{O} \boldsymbol{R}=\mathbf{3 , 7 8}$ kali 
untuk menderita $\mathrm{PIH}$ dibandingkan subyek yang berumur 20-35 thn. Hal ini sesuai dengan penelitian yang dilakukan oleh Irfan et al , mendapatkan hasil bahwa faktor umur ibu yang beresiko yaitu berkisar dibawah 20 tahun dan diatas 30 tahun untuk menderita PIH dan preeklampsia. Serta juga adanya resiko bagi wanita untuk mengalami mudah mendapat $\mathrm{PIH}$ yaitu : wanita yang berumur lebih dari 40 tahun . (americanpregnancy . 2002)

Faktor paritas ( multipara dan primipara ) sendiri berdasarkan persentase dan test crosstab chisquare memperlihatkan bahwa faktor multipara persentase (50\%) lebih tinggi untuk menderita $\mathrm{PIH}$ dibandingkan ibu Primipara dengan persentase $(31,6 \%)$, dan resiko untuk menderita PIH sekitar 2,166 kali lebih besar dibandingkan faktor primipara yang hanya mempunyai odds Ratio (OR) sebesar 0,57. Hal ini diperkuat oleh adanya artikel yang dimuat pada (jurnal americanpregnancy ,2002 ) tentang faktor multipara yang lebih besar pengaruhnya dibandingkan dengan primipara, walaupun hal ini berbeda dengan hasil yang didapat oleh (Putu S dari bagian Obgyn RSUD Tarakan Kaltim) yang memberikan kesimpulan PIH dan Preeklampsia lebih sering terkena pada primipara.

Hubungan faktor Index Masa Tubuh (IMT) ibu hamil terhadap resiko menderita PIH pada data kami setelah diolah secara test crosstab-chisquare , secara persentase bahwa pada kelompok ibu hamil dengan IMT tinggi lebih besar yang menderita $\mathrm{PIH}$, serta mempunyai resiko (OR) 1,67 kali lebih banyak dibandingkan kelompok ibu hamil dengan IMT normal. Hal ini sesuai dengan keterangan yang berasal dari (The Cleveland Clinic (c) 1995-2008), yaitu salah faktor resiko untuk menderita PIH adalah ibu hamil yang memiliki berat badan criteria underweight dan overweight.

Pengaruh polymoprhisme gen endothelial nitrit oxide syntase (eNOS) Glu298Asp terhadap resiko kejadian $\mathrm{PIH}$ walaupun secara signifikansinya kurang bermakna $(p>0,05)$, tetapi apabila dilakukan test crosstabs chisquare untuk melihat besarnya resiko dari masing-masing genotype eNOS gen, didapatkan hasil pengolahan faktor resiko sebesar $(O R=1,8)$ kali untuk genotype $G G$, genotype GT $(\mathrm{OR}=0,5)$, sedangkan genotype TT tidak ada. Jadi, genotype GG yang paling berpengaruh untuk menimbulkan kejadian PIH . Hal ini sejalan dengan 
hasil penelitian yang didapatkan oleh yang Makrina D et al 2001, yang mendapatkan hasil pengukuran maternal FMD pada arteri brachialis berupa polymorphisme eNOS GLU298ASP genotype Glu/GLU (GG) homozygte lebih besar pengaruhnya terhadap vasodilatasi arteri brachialis ibu dibandingkan dengan genotype GT maupun TT homozygote. Akan tetapi, hal ini sedikit berbeda apa yang telah diteliti oleh Rossi GP et al (2001) ; Melaporkan adanya respon yang menekan pengaruh pemberian phenylephrine terhadap reaktivitas vaskular lebih tinggi pada manusia yang membawa allele T ( GT dan TT, Asp298) dibandingkan GG homozygous.

Pada data kami mengenai interaksi polimorphisme eNOS gen dengan faktor-faktor resiko ibu hamil untuk menderita PIH yang kami oleh melalui test crosstab-chisquare untuk melihat persentase utamanya Odd Ratio (OR) masing - masing variabel, maka didapatkan bahwa interaksi eNOS gen dengan faktor umur paling besar Odd Rationya sebesar 4,25 kali untuk menderita PIH utamanya pada kelompok umur ibu hamil antara kurang dari 20 tahun dan lebih dari 35 tahun, dibandingkan interaksi antara polimorphisme eNOS gen dengan faktor paritas dan faktor IMT ibu hamil. Dengan demikian, dapat ditafsirkan dari hasil data kami, bahwa adanya interaksi antara polimorphisme eNOS gen dengan faktor umur ibu hamil utamanya yang berumur antara dibawah 20 tahun dan diatas 35 tahun akan meningkatkan resiko untuk menderita $\mathrm{PIH}$. Sedangkan interaksi antara polimorphisme eNOS gen dengan faktor paritas dan IMT ibu hamil tidak memperbesar resiko untuk menderita $\mathrm{PIH}$.

Faktor sinergisme dari variabelvariabel independent terhadap peningkatan kejadian PIH ternyata kami tidak menemukannya secara bermakna melalui test crosstabchisquare dengan melihat Odd Ratio (OR) pada interaksi maupun sinergisme diantara faktor-faktor resiko pada data kami untuk menderita PIH . Jadi, kami mengambil kesimpulan bahwa tidak terdapat sinergisme untuk saling memperbesar resiko menderita $\mathrm{PIH}$ dari variable-variabel independent yang kami teliti, dan masing-masing variable independent atau faktor faktor tersebut saling berdiri sendirisendiri dalam menimbulkan kejadian $\mathrm{PIH}$. 


\section{KESIMPULAN}

Berdasarkan hasil penelitian ini melalui pendekatan persentase maupun Odd Ratio dapat disimpulkan bahwa faktor umur ibu hamil kurang dari 20 tahun dan lebih dari 35 tahun mempunyai resiko lebih besar untuk menderita $\mathrm{PIH}$ dibandingkan umur 20 tahun sampai 35 tahun. Dan untuk lbu yang multipara akan lebih besar beresiko untuk menderita $\mathrm{PIH}$ dibandingkan primipara. Demikian juga Ibu hamil yang mempunyai IMT tinggi akan beresiko lebih besar dibandingkan ibu hamil yang memiliki IMT yang normal. Serta faktor Polymorphisme gen eNOS genotype GG pada ibu hamil mempunyai resiko untuk mendapat $\mathrm{PIH}$ lebih besar dibandingkan genotype non GG.

Interaksi antara polimorphisme eNOS gen genotype GG dengan faktor umur ibu hamil utamanya kurang dari 20 tahun dan lebih dari 35 tahun akan meningkatkan resiko untuk menderita $\mathrm{PIH}$. dibandingkan interaksi antara polimorphisme eNOS gen dengan faktor paritas dan faktor IMT ibu hamil. Dengan demikian, dapat ditafsirkan dari hasil data kami, bahwa adanya interaksi antara polimorphisme eNOS gen dengan faktor umur ibu hamil utamanya yang berumur antara dibawah 20 tahun dan diatas 35 tahun akan meningkatkan resiko untuk menderita PIH. Sedangkan interaksi antara polimorphisme eNOS gen dengan faktor paritas dan IMT ibu hamil tidak memperbesar resiko untuk menderita PIH. Serta tidak ada sinergisme yang berperan dari variable-varibel independent terhadap kejadian $\mathrm{PIH}$.

\section{DAFTAR PUSTAKA}

Glowinska B , Urban M. Selected cytokines ( II-6, II-8, II-10, MCP-1, TNF-alpha) in children and adolescents with atherosclerosis risk faktors : obesity, hypertension, diabetes. Wiad Lek. 2003 ; 56(3-4) : 109-16

Guy V, Sawle, Margaret M Ramsay. The Neurology of Pregnancy. J Neurol Psychiatry 1998; 64:711-725

Hans P Schobel et al. Preeclampsia A State of Sympathetic overactivity. $N$ Engl J Med 1996; $335: 1480-85$

Joey P. Granger et al. Pathophysiology of hypertension during preeclampsia linking placental ischemis with endothelial dysfunction. Hypertension. 2001; 38: 718722

Thomas F. Luscher and Matthias Barton. Endothelins and endothelin receptors antagonist. Circulation. 2000; 102: 2434-2440.

Shah DM. Role of the reninangiotensin system in the 
pathogenesis of preeclampsia. Am J Renal Physiol 288: F614-F625, 2005

Woisetschlager C. et al. Inceased blood pressure respons to the cold pressure test in pregnant woman developing pre-eclampsia. J Hypertens, April1, 2000: 18 (4) : 399-403

Maisuri TC, Yusuf I, Idris I. Prevalence of tumor necrosis faktor- $\alpha$ and angiotensin converting enzyme (ACE) gene polymorphisms in preeclampsia; an immunogenetic phenomenon ?. Department of Obstetrics \& Gynecology , Department of Physiology, School of Medicine and Laboratory of Biotechnology Research Centre Hasanuddin University, Makassar, 2002.

Idris Irfan, Agnes B : Hubungan Peningkatan Hiperaktifitas Simpatis dengan Kejadian Preeklampsia dan Hipertensi Pada Ibu Hamil, dalam Jurnal Penelitian Pascasarjana Universitas Hasanuddin, 2005.

Guyton AC : Hipertensi dalam Buku Fisiologi Manusia dan Mekanisme Penyakit, Lange EGC, Edisi Revisi, Penerbit Buku Kedokteran Jakarta, 1991

Ganong WF : Hipertensi, Homeostatis Cardiovascular dalam keadaan Sehat Dan Sakit dalam Buku Fisiologi Kedokteran, Lange EGC, Edisi 20 , Penerbit Buku Kedokteran , Jakarta, 2002 : $615-16$.
Anwar R, Agoestina T. Tinjauan Morbiditas dan mortalitas preeklampsia berat dan eklampsia di RHS Bandung 199 - 1994. Kumpulan Makalah ilmiah PTP V POGI. Surabaya $1995: 247-64$

I.K. Suwiyoga. I.NH. Sanjaya. Risiko bayi kecil masa kehamilan pada iskemia, infarka dan hidrops vili plasenta. Majalah Obstetri dan Ginekologi Indonesia. Vol. 28. No. 1 Jakarta : 2004: 3 - 5 .

Hermida RC et al. Blood Pressure Pattern in Normal Pregnancy, Gestational Hypertension, and Preeclampsia. Hypertension. 2000 : 36: 149 $-158$

Rosas, Vargas $\mathrm{H}$ et al. Glu298Asp endothelial nitrict oxide synthase polymorphism is risk faktor for erectile dysfunction in the Mexican Mestizo population.J Androl.2004 SeptOct;25:728-32.

Berdeli A, Sekuri $C$ et al. Assosciation between the eNOS (Glu298Asp) and the RAS genes polymorphisms and premature coronary artery disease in a Turkish population. Clin Chim Acta. 2005 Jan;351(1-2):87-94.

Fatini C, Gensini $F$ et al. High prevalence of polymorphisms of angiotensine-converting enzyme (I/D) and endothelial nitric oxide synthase (GLU298Asp) in patients with systemic sclerosis. Am J Med.2002 May;112(7):540-4.

Rossi GP et al ; The T-786C and Glu298Asp polymorphisms of 
Interaksi Faktor Polimorphisme Gen Endhotelial Nitric Oxide Sintase (ENOS)

the endothelial nitric oxide gene affect the forearn blood flow responses of Caucasian hypertensive patients. J Am Coll of Cardiology 2003;41: 938-45.

Cervenka $L$ et al : Role of nNOS in regulation of renal function in angiotensi Il-induced

hypertension.

Hypertension.2001;38:280285.

Ignarro L.J. (2001): Nitric Oxide. A Novel Signal Transduction Mechanism For Transcellular Communication; 16: 477- 483 